SOGIAL GROUPS IN POLISH SOGIETY 


\section{Social Groups in \\ Polish Society}

Edited by

DAVID LANE

Reader in Sociology in the University of Essex

and

GEORGE KOLANKIEWIGZ

Lecturer in Sociology in the University of Essex

Macmillan Education 
ISBN 978-1-349-01103-2 ISBN 978-1-349-ol101-8 (eBook) DOI 10.1007/978-1-349-01101-8

(c) David Lane and George Kolankiewicz 1973 Softcover reprint of the hardcover 1st edition 1973 978-0-333-12177-1

All rights reserved. No part of this publication may be reproduced or transmitted, in any form or by any means, without permission.

First published 1973 by THE MACMILLAN PRESS LTD

London and Basingstoke Associated companies in New York Toronto Dublin Melbourne Johannesburg and Madras

SBN 333 I2I 775 


\section{Publishers' Note}

The series of eleven volumes entitled 'Political and Social Processes in Eastern Europe' is the result of a British interuniversity, inter-disciplinary comparative study, sponsored by the Social Science Research Council. Professor Ghiţa Ionescu was the organiser and co-ordinator of the research work (1968-7I).

The volumes are as follows:

Ghiţa Ionescu (University of Manchester): The Evolution of the Socialist State

Jane Cave (University of Birmingham), R. Amann (University of Birmingham), L. Blit (University of London), R. W. Davies (University of Birmingham), T. Podolski (Portsmouth Polytechnic), and G. Sakwa (University of Bristol): Politics and the Polish Economy

David Lane (University of Essex) and George Kolankiewicz (University of Essex) (editors): Social Groups in Polish Society

Jaroslav Krejčí (University of Lancaster): Social Change and Stratification in Postwar Czechoslovakia

Vladimir V. Kusin (University of Glasgow): Political Grouping in the Czechoslovak Reform Movement

A. H. Brown (University of Oxford) and G. Wightman (University of Liverpool): The Communist Party in Czechoslovakia

J. F. N. Bradley (University of Manchester): Czechoslovak Politics 1948-68 Phyllis Auty (University of London): The Changing Role of the Yugoslav Communist Party

R. K. Kindersley (University of Oxford): The Yugoslav Federal Assembly: Relations between Executive and Legislature

F. Singleton (University of Bradford): The Yugoslav Social Groups and Institutions

D. Matko (University of Glasgow) and D.J. R. Scott (University of Glasgow): Career Patterns of Yugoslav Decision-Makers

The individual volumes have different titles and each of them is a selfcontained, independent study on a separate subject.

Together they form a tripartite analysis of three given Socialist states of Eastern Europe: Czechoslovakia, Poland and Yugoslavia, as follows: 


\begin{tabular}{llll}
\hline Subject of study & Poland & Czechoslovakia & Tugoslavia \\
\hline $\begin{array}{l}\text { The changing role } \\
\text { of representative } \\
\text { institutions }\end{array}$ & Jane Cave & J. F. N. Bradley & R. K. Kindersley \\
\hline
\end{tabular}

The changing role Jane Cave

A. H. Brown and Phyllis Auty of the Party

G. Wightman The changing role
of the groups in the interplay between the government and the economy

L. Blit, Jaroslav Krejčí F. Singleton

R. W. Davies,

R. Amann, Vladimir V. D. Matko and $\begin{array}{lll}\text { and T. Kusin } & \text { D. J. R. Scott }\end{array}$ Podolski

\section{David Lane and George Kolankiewicz}

See for a complete description of the project in the Appendix of The Evolution of the Socialist State, by Ghiţa Ionescu in this series.

Each book in the series will carry its own index of names and subjects. When all eleven volumes have been published a complete synoptical index to the series will be published. 


\section{Contents}

List of Tables viii

List of Diagrams and Map xii

List of Tables in Appendixes xiii

Preface $\quad \mathrm{xV}$

I Structural and Social Change in Poland I David Lane

2 The Peasantry 29

Paul Lewis

3 The Working Class 88

George Kolankiewicz

4 The Cultural Intelligentsia: The Writers I52 George Gömöri

5 The Technical Intelligentsia $\quad$ 180 George Kolankiewicz

6 The Local Political Élites 233 Ray Taras

7 The Role of Social Groups 302

David Lane

Appendixes $\quad 327$

Terms and Abbreviations $\quad 346$

Bibliography $\quad 349$

List of Contributors $\quad 366$

Index $\quad 367$ 


\section{List of Tables}

I Poland's Industrial Resources (Prewar and Postwar)

2 Occupational Structure of the Polish Population, I93I and ig6o

3 Population by Main Source of Income (per cent) I93 I, I950 and r96o

4 Full-time Graduates of High Technical Schools by Sex, I946-6 I

5 Number of Vocational School Pupils

6 Number of Students in Higher Educational Institutions (ooo's)

7 Social Composition of Students in Higher Education (per cent)

8 Expenditure of Manual and Non-manual Workers in 1966 and 1968

9 Educational Level of Employees in the National Economy in $195^{8}$ and 1968 (per cent)

ro Status of Various Occupational Groups

I I Ranking of Occupations

I 2 Size of Factory and Number of Workers' Councils

I 3 Growth of Consumption per Inhabitant, of Real Income per Person, and of Average Real Wages per Person and per Family

I4 Gross Monthly Income of Manual Workers and its Growth in Selected Industries

I5 Income per Person per Month in Manual and Non-manual Households (I962)

I6 Participation in Enterprise Fund According to Socio-occupational Categories 
I 7 Structure of Accommodation Density According to Socio-occupational Category

I8 Students in their First Year of Full-time Study According to Social Origin

I9 Relationship between Growth in Employment and Number of those Coming to Employable Age

20 Industrial Manual Workers and the Distribution of Gross Monthly Income for September 1965 and I967

2 I Relationship between Family Size and Expenditure upon Foodstuffs for Manual and Non-manual Households (1968)

22 Years in which Respondents felt they were best off (per cent)

23 Skilled Workers as Percentage of Total Manual Worker Party Membership by Industries

24 Organisational Membership by Industrial Sociooccupational Category

25 Socio-occupational Composition of Selfmanagement Organs in the Transport Construction Industry

26 Socio-occupational Composition of the Selfmanagement Organs at the Aluminium Works of Skawina

27 Participation of Manual Workers in Selected Trade Union Posts and Organs (1968)

28 Growth in the Number of Party Members in a Selected Technical School

29 Management Level and Premium Paid as a Percentage of Basic Salary

30 Inter-branch Proportions in Income of Certain Technical Posts in 1964

3 I Membership of the Supreme Technical Organisation and Party amongst a Selected Group of Engineers 207

32 Participation in the Party and STO by Various Grades of a Selected Group of Technical Staff

33 First Year Students of Worker and Peasant Social Origins receiving Higher Education (per cent)

34 Social Origin of Engineers in Various Sections of the Electrical Engineering Industry (per cent) 
35 The Structure of Earnings amongst Various

Occupational Categories with Higher Education Employed within the Nationalised Economy in January I968

$3^{6}$ Career-type and Social Origin of Industrial Enterprise Directors

37 The Initiators of Resolutions Passed by Councils 222 and Presidia in Kraków Wojewodstwo in I 962

$3^{8}$ The Initiators of Resolutions Passed by Five Councils and Presidia in Wrocław Wojewodstwo in 1955 (in per cent)

39 Controls, Binding Advice and Opinions, Normal Opinions exercised by Commissions between I January I966 and 31 March I967

40 Assessment of Legal Regulations by Department Heads (in per cent)

4I Respondents' Opinion about Contact with their Councils

42 Results obtained in Council Settling an Issue and Opinion on Contact with Council (per cent)

43 Opinion on Reasons for Shortcomings and Neglect in Council Work (per cent)

44 Channels of Appeal which would be/were used against Mismanagement/Unsatisfactory Decision of Official Institution/Council by Citizens in Local National Survey (per cent)

45 Managerial Status of Members of Socio-political Organisations in Zawodzie

46 Types of Units which had Controls Performed on them by Commissions in Łódź in 1962-3

47 Representatives from Undertakings not

Subordinated to Council who Participated in Presidium Sessions in Eleven Towns in Łódź Wojewodstwo (1962-3)

48 Aspects of Decision-Taking in Zawodzie in 1962

49 Numbers of Councillors, Presidium Members, Commission Members and Departmental Nonmanual Workers in Councils over Time and According to Administrative Level 
50 The Permanent, Directing Members of Presidia of People's Councils according to their Social Origin in 1969

5I Councillors of Presidium Members in I969 Employed in Selected Sectors of the National Economy (per cent)

52 Sources for Recruitment of Presidium Members in I9 Powiats and Non-Powiat Towns in Lublin and Rzeszów Wojewodstwos in 1963

53 Sources for Recruitment of Presidium Members in twelve Wojewodstwos, Powiats and Non-Powiat Towns and Wards in Łódź Wojewodstwo in 1964 


\section{List of Diagrams and Map}

Diagram I The Wielka Czworrka: The Leading Group within the Enterprise

Diagram 2 The Enterprise Director as a Focus of Demands

Diagram 3 Structure of Subordination in the People's Council System

Diagram 4 Internal Structure of a Powiat Council 238

Diagram 5 Types of Further Education of Presidium Members in 1969 and Administrators in 1965

Map I Poland after the Second World War 


\section{List of Tables in Appendixes}

Table I Population Statistics

APPENDIX 2

Table I Rural and Agricultural Population $\quad 328$

Table 2 Organisation of Agriculture $\quad 329$

Table 3 Structure of Private Agriculture 330

Table 4 Political Mobilisation of the Peasantry 33 I

Table 5 Composition of Small-holding Peasant

Members (1965) $33^{2}$

Table 6 Rural Party Membership (1965) 333

APPENDIX 3

Table I Enterprise Directors and Party Membership (I945-55)

Table 2 Enterprise Directors and Social Origin (1945-64)

Table 3 Enterprise Directors and Educational Qualifications (I945-8)

Table 4 Enterprise Directors and Educational Qualifications (1949-52)

Table 5 Enterprise Directors and Educational Qualifications (I953-5)

Table 6 Enterprise Directors and Educational Qualifications (I956-8)

Table 7 Positions held directly prior to Promotion to Post of Enterprise Director (1965)

Table 8 Graduates of Higher Technical Colleges by

Day (Full-time) Courses According to Social Origin 
xiv

Social Groups in Polish Society

APPENDIX 4

Table I Level of Education of Councillors at

Wojewodstwo, Powiat and Gromada Level

between 1949 and 1969

Table 2 Level of Education of Presidium Members at

Wojewodstwo, Powiat and Gromada Level

between 1947 and 1969

Table 3 Level of Education of Non-manual Workers

Employed by Presidia at Wojewodstwo,

Powiat and Gromada Level

Table 4 Socio-occupational Groups of Councillors at

Wojewodstwo, Powiat and Gromada Level between 1946 and 1969

Table 5 Socio-occupational Groups of Presidium

Members at Wojewodstwo, Powiat and

Gromada Level between 1947 and 1969

Table 6 Party Membership of Councillors between I 946 and 1969

Table 7 Party Membership of Presidium Members between 1947 and 1969 


\section{Preface}

The subject of this book is the study of social groups in Poland. By a 'group' in its widest sense we mean an aggregate or category of persons having relationships with each other, possessing common qualities or features which sometimes give rise to shared norms and values. We do not claim that social groups are the only or necessarily the most important aspect of social and political change. But we do believe that a fuller appreciation of politics may be afforded by an understanding of the group structure. In the past, studies of East European societies after the Second World War have overwhelmingly concentrated on political groups and processes to the exclusion of the social. We hope that this book will help redress the balance as far as Poland is concerned. We take the view that the study of the formation of social groups is important in its own right as well as providing insight into the political process. The industrialisation process carried out by the Communist élites in the State socialist societies of Eastern Europe has had a momentous impact on the social structure of these countries which we seek to describe and thereby to show the interaction of political and social forces.

The book is arranged in the following way. The first chapter is a general introduction to the changing social, political and economic structure of Poland both before and after the foundation of the People's Republic of Poland. Whereas this chapter is a macro study, the ones which follow are micro studies, each dealing with a particular social group: the working class, the peasantry and the intelligentsia. We have organised the study around social groups, rather than on themes, to facilitate comparative study of these phenomena in the other two countries which comprise this series (Yugoslavia and Czechoslovakia). These general social groups have been found to include many sub-groups which have made a complete description impossible. We have, therefore, in addition to a general introduction on 
each group, focused in some chapters on a more detailed study of one sub-group: in the case of the cultural intelligentsia, we have considered the writers and their expression through the Polish Writers' Association; the technical intelligentsia has been limited to engineers and directors of enterprises. Each study attempts to describe the changing structure of the group. We have indicated the ways demands are made on the political system, and in the chapter on local political authorities we have studied the interaction of social groups in the locality. We hope that a following volume in this series will emphasise the more political significance of these studies as it concentrates more on political institutions and processes. In this following book too is a study of the Roman Catholic Church in Polish society. The time period covered for each subject in this volume is from 1945 to the assumption of the leadership of the Polish United Workers' Party by Gierek and the emphasis is on the later Gomulka epoch. In the conclusion some tentative points are made about changes which have taken place in I97I as well as a general summing-up of the significance of the various studies.

We are indebted to many people and institutions who have made this book possible. The monograph was inspired by Professor Ghiţa Ionescu, who has acted as the co-ordinator of the comparative study on Poland, Czechoslovakia and Yugoslavia of which the study is a part. The British Social Science Research Council played a major part in providing finance which enabled George Kolankiewicz to work full-time as a research fellow on the project and facilitated visits to Poland to collect information by him and Ray Taras. We would like to express our thanks to the following for help given to the authors in the course of their work: the Institute of Sociology of Warsaw University, the Institute of Administration and Management of Warsaw University, the Polish Library, London.

We are also grateful to David Bouchier, Christel Lane, Ray Taras, Ros Patton, who have read parts of the manuscript and have made many useful suggestions, and to Ilse Browne and Luise Dobson, who typed the manuscripts.

Department of Sociology

University of Essex
David Lane

GeORge KolankIEWICZ 